\title{
THE SACRED GROVES OF THE BALTS: LOST HISTORY AND MODERN RESEARCH
}

\author{
Vykintas Vaitkevičius
}

\begin{abstract}
The article deals with the sacred groves of the Balts in Lithuania and presents the linguistic background, the historical documents from the 12th18th century, the key folklore motifs of the topic, as well as selected examples of groves. The article also discusses possible relationships between pre-Christian religious traditions connected with the sacred groves and the ones which have survived into the 21 st century.

Despite the fact that the sacred groves of past ages have mostly disappeared on the landscape, this tradition has not significantly changed. Various religious activities which were carried out in sacred groves, at smaller groups of trees, and beneath separate trees enable us to learn, even if insignificantly, about the phenomenon. Interdisciplinary approach to sacred groves should be preferred in modern research.
\end{abstract}

Key words: Lithuania, natural holy places, sacred groves, sacred trees, the Balts

\section{INTRODUCTION}

Sacred grove was a universal type of natural holy places in the ancient world. It was prevalent among the Balts in prehistoric and also historic times. However, researchers are in sad lack of special knowledge while examining culture that is based on oral tradition. The materials to be used in research are often scattered, indeterminate, and unattractive in academic terms.

The list of previous works on the sacred groves of the Balts is rather short. National as well as international audience needs more comprehensive materials and explanation. The most remarkable progenitor in this field is the Latvian archaeologist Eduards Šturms. His study Die Alkstätten in Litauen (1946), in which the main outlines for further investigations were drawn, is still relevant. Furthermore, the study presents a list of natural holy places, including the sacred groves. ${ }^{1}$ In later years only some references were made (cf. Šturms 1948; Wenskus 1968; Urtāns 1989) and now, after a long pause, the study of the sacred groves of the Balts has been undertaken again (Vaitkevičius 2004: 16ff). 
General studies into the so-called 'tree worship' provide us with some references to the sacred groves mentioned in written sources (cf. Ivinskis 1938/ 1986; Balys 1966: 62ff; Dunduliene 1979) and these are used to illustrate all theoretical theses on the subject. However, a grove differs from a stone or hill in terms of its existence which should be specified in many ways as temporary. This specific feature of the groves as well as its changing size and outside appearance, has not yet enabled researchers to present final conclusions. The questions concerning the religious and social role of the sacred groves in preChristian religion have remained open so far. There are some more important aspects to mention: namely, gods associated with trees, a tree's "gender" in the Lithuanian folk worldview system, and relationships between tree and man depending on the age of the latter (which changed with respect to one's social status).

The example of oak and lime tree is perfectly well known among mythologists and folklorists - these trees represent the god of thunder (Lith. Perkūnas, Lat. Pêrkons) and the goddess of fortune (Lith. and Lat. Laima), respectively. However, this is not the only example. The famous tale "Egle the Queen of Grass Snakes" (AT 425M) has been recorded in numerous versions in both Lithuania and Latvia. At the centre of this tale there is a mother called Eglè, who turned into a fir tree, her three sons turned into an oak, a birch and an ash, and her daughter became an aspen. Eglè's husband was believed to be a grass snake called Žilvinas (cf. Lith. žilvytis 'osier') (further on this topic see Martinkus 1989). Despite all exertions by researchers to reveal the specific meaning of this mythological narration, it is still shrouded in mist.

\section{LINGUISTIC BACKGROUND}

Sacred groves are the central subject of this article. Here, linguistics provides some essential details to support the research. There are words alka (fem.) and alkas (masc.) which have the meaning of 'a sacred grove', 'a place where sacrifices were burnt', and 'sacrifice' in the Lithuanian language (Balčikonis 1941: 84), and elks or 'idol' in Latvian (Karulis 1992: 264). Next to Lithuanian gojus 'small, beautiful grove' and Lithuanian šventas, the Latvian svēts 'holy' quite often appears as equivalent for $\operatorname{alka(-s)}$ and elks. The terms alka(-s) and elks are the most commonly used names (sometimes elements of compound place names) which mark natural holy places of different types in Lithuania and Latvia, thereby indicating the close ties between sacred groves on the one hand and hills, fields, and water bodies, on the other (120 Alka hills, 70 Alka fields, 50 Alka lakes, rivers, and wetlands have been registered in Lithuania 
and Latvia). There are some other examples: historically attested proper names of the sacred groves sometimes correspond to the names of rivers located in the same, or approximately the same, region (cf. place names Asswyiote and Ašvija). It seems reasonable to assume that the sphere of the sacredness of the Baltic gods and/or deities used to entail more than only one grove: it was spread over a particular geographical area, including various sites and objects like rivers, lakes, and hills (for example, potential cult sites).

Some available data is rather fragmentary. The number and significance of the sacred groves have diminished over the last 600 years. In this situation it is practical to register and examine the remnants of sacred woodland areas rather than the actually extant pre-Christian cult sites.

\section{EVALUATION OF HISTORICAL SOURCES}

Adam of Bremen was the first to mention the sacred groves of the Baltic tribes, while talking about Prussians in c. 1075. According to him, the entrance to the sacred groves and springs was inaccessible for Christians to avoid the pollution of a particular holy place (solus prohibetur accessus lucorum et fontium, quos autumant pollui christianorum accessu) (Vèlius 1996: 190ff). Very likely the note is connected with the Sambian Peninsula. In the 14th-century documents, left by members of the Teutonic Order, a few sacred groves are mentioned to have existed in the above region (e.g., sacra sylva, que Scayte vulgariter nominatur..., silva, quae dicitur Heyligewalt...) (Vèlius 1996: 319ff). Historian Reinhard Wenskus (1968: 322) has determined that sacred groves covering relatively small areas on the Sambian Peninsula have separated one village from another.

In the 14th-15th century, sacred groves became the focus of the Teutonic Order in Samogitia (the western part of modern Lithuania). Though described in geographical terms, sacred groves were mentioned in documents only as well-known landmarks (e.g., von deme heyligen walde von Rambyn..., II mile bis czü Saüten czü deme heiligenwalde...) (Vèlius 1996: 429ff). Authors of the same period from Poland, Czechia, and other countries have described tree and sacred grove worship as a general but important phenomenon, characteristic of pagans (cf. Historia Polonica, Vèlius 1996: 556ff).

A number of 16th-century documents, including detailed descriptions of land and property (sometimes also accompanied by drawings), are stored in the Lithuanian archives. These facilitate updating the database of the sacred groves with geographically precisely localized material; however, this data still needs investigation. 
In the second half of the 16 th century, the first reports by Jesuit missionaries emerged. Together with other traces of paganism (e.g., fire worship), sacred groves are described in these reports often enough. These descriptions, dated to the early 17 th century, are unique in many respects although they lack detailed localization of the observed subjects (cf. Vèlius 2001: 618ff). It is characteristic of the latter period that similar sources on the Baltic people (also partly Germanized) are available from the neighbouring Livonia and Eastern Prussia. Owing to the remarkable accuracy of the descriptions of rituals and mythological imaginations, the manuscript Deliciae Prussicae, oder Preussische Schaubühne by Matthaeus Praetorius (c. 1635-1704) is of particular interest.

A pastor by profession, Praetorius was historian and ethnographer all his life. His main research subject was Old Prussians and Lithuanians living within the territory of Eastern Prussia. Praetorius has written an 18-volume manuscript on the history of Prussia. In three volumes (vols. 4, 5, and 6) he refers to religious customs, beliefs, and festivals associated with various spheres of the private and public life (Lukšaitè 2006).

Materials recorded by Praetorius are often unique and versatile sources for research. He also presented some remarkable drawings (Fig. 1). Praetorius'

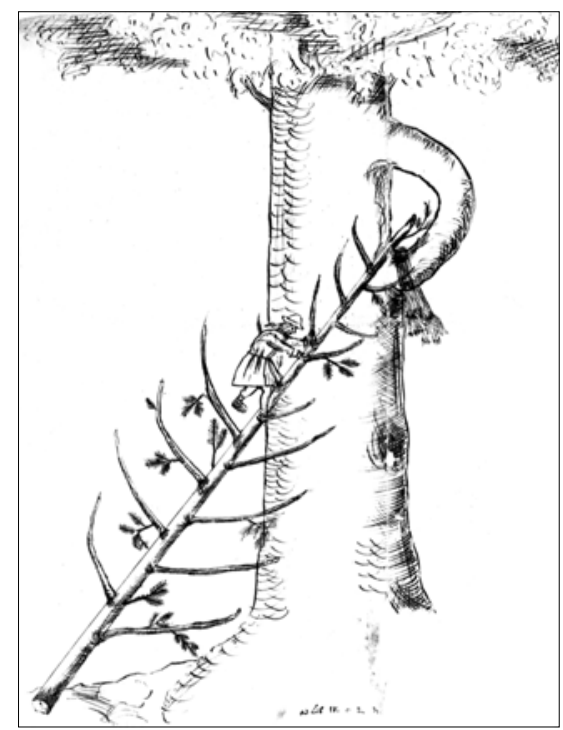

Figure 1. Die Eiche im Ragnitischen Felde ('Oak on the Ragnit Field'). Drawn by Matthaeus Praetorius before 1699 (Lukšaitè 2006: 118-119). An ill person is climbing up an oak tree to a special hole, through which a piece of cloth has been tied. work provides important evidence in the form of narration: especially one narration tells about how a particular tree could be turned into a sacred tree. For this purpose, a person (who was usually called vaidutis 'priest'), a member of the preChristian priesthood, summoned the 'God' to the tree. During this ceremony, which lasted for three days, the priest went on a fast. If nothing happened, the priest needed some blood (of his own or children's) to stain the treetrunk with it. After this act (which Praetorius has called, very likely under the influence of Christian terminology, 'consecration'), sacrifice was made and a festival was held near the sacred tree.

When talking about the 18 th century, a huge amount of descriptions of land and property has to be taken into account. There are also some original (or at least 
partly original) works which deal with the ancient sacred groves and remnants of pre-Christian religion in the then culture. The 19th-century authors (Narbutt, Daukantas, and others) who tried to become researchers rather than being passive observers added importance to the discussed topic.

In sum, historical sources are rich in particular details concerning sacred groves. The data is highly valuable, although it generally lacks precise geographical information. Only 13 forests and groves have been mentioned in the 14th- to 17th-century sources altogether; the location of these 13 could be determined, at least approximately (Vaitkevičius 2004: 17). Although in historical sources (see Vèlius 1996: 595ff) the central part of the sacred groves has sometimes been regarded as a 'residence of the gods', its location cannot be determined today.

The sacred groves have been often turned into fields or can be traced only in place names on the landscape. A telling example is the groves called Gojus, which are mentioned in 17th- and 18th-century historical sources in huge numbers. By the end of the 19th and the beginning of the 20th century, these had already mostly become cultivated fields and meadows. While it is truly fortunate that a sacred grove mentioned in historical sources can be identified as a present-day grove, at the same time one should be content with the very idea about the sacred grove as a sacred space in general and in terms of some already lost details. Beasts and birds living in the sacred grove were distinguished by having a special status and religious ceremonies held in the sacred groves were inspired by conceptions about the gods and the dead. Of course it was strictly forbidden to break a branch or cut a tree in the grove:

Heyligwald [= sacred grove] [...], beautiful trees grow there, tall birch trees and junipers underneath. Samogitians still believe it to be sacred; it is forbidden to cut trees there so that the gods that live in the wood would not be injured. (Vèlius 2001: 326, 339) ${ }^{2}$

Special attention should be given to the presence of East-Lithuanian barrow groups (which are characteristic of the 5th-12th century and contain mainly cremation burials) in the Gojus groves. Such links between burials and areas of sacred groves allows a reasonable presumption that sacred groves have functioned as cultic places, although a precise description of the latter remains a subject for special study.

\section{IMPORTANCE OF FOLKLORE}

Despite the fact that real, or "academically acceptable" history does exist in written form while folklore exists in oral, they are not alternative from the viewpoint of the present study. Tales, legends, and beliefs often serve as ex- 
planations of specific place names marking the sacred groves. Next to Alka, Šventas (Holy) and Gojus groves, one could mention Perkūnas (God of Thunder), Laumè (Fairy), Dievas (God) and Velnias (Devil) groves. Sometimes these sites mentioned in folk narratives coincide with historically documented groves but more often they do not. In any case, from the aspect of folklore, the panorama of sacred groves is significantly wider. Pieces of folklore, such as mythological tales and place legends, allude to the mythological aspects of sacred groves, which have never been recorded by historians.

First, numerous mythological tales clearly suggest that the woods in general and sacred groves in particular have been viewed as strange and usually unfamiliar space, which was full of mythical power manifest in various forms in the natural world: plants, animals, etc. In the mythological sense these manifestations were closely related to the gods and deities: for example, hares were regarded as the hounds of goddess Medeina (equivalent of Greek Artemis and Roman Diana) and juniper was connected with the concept of life and rebirth and at the same time with some celestial gods: Perkūnas (god of thunder) and Saule (the Sun). Obviously, folklore materials could shed light on some important features of mythology in the general pattern of the prehistoric worldview.

Second, according to folk narratives, pathway to the other worlds often leads through the woods - sacred groves. Those who travelled to these worlds often encountered gods or the dead on their journey. In oral tradition about sacred groves in Lithuania, recorded in the late 19th and the 20th century, both above possibilities can be recognized: Velnias (Devil) can be visited in his home (see the popular tale type "The Musician at the Devils' Feast"), while white beings in the shape of humans can be encountered or burning money (gold) observed. These are classical images of souls in the Baltic mythology (cf. Vaitkevičienè 2001: 57ff). The same concept of souls being trapped in trees as in purgatory (according to Christian terminology) is reflected in legends referring to groves and separate trees as places of execution or accidents. This led to either avoidance of or respect towards these places among the people.

Mentions of any ritual ceremonies (either pre-Christian or Christian) having been performed in the sacred groves are exceptionally rare. Moreover we cannot rule out the possibility that such motifs like "People used to gather to the grove for celebrations in very ancient times" or "Pagan sanctuary was in use in the grove. Holy fire was supervised by competent girls (vaidilutes 'servants of the pagan priest')" were created or re-created during the 19th and early 20 th century.

Despite the late chronology of folklore materials (the 19th-20th century), they verify the existence of sacred groves in the areas inhabited by the Baltic tribes in the distant and the more recent past. Quite often the subject of oral 
tradition still exists, and illustrates, in the form of human cultic activities (or results of these activities) the different manifestations of mythological and religious ideas.

\section{SACRED GROVES IN THE MODERN WORLD}

Traditions connected with sacred groves and especially individual sacred trees were alive in the 19th-20th century, and still are in the early 21 st century. However, compared to the pre-Christian period, the sacredness of groves and trees seems to be somehow dispersed. Sometimes the sacredness is present in small woodland areas in the form of a local natural holy place, sometimes it has been associated with nearby churches or rural cemeteries. It is occasionally located in villages and farmsteads or in their immediate surroundings.

The local holy places in groves and forests are located mostly in Samogitia, the ethnographical region in western Lithuania with a predominantly Catholic population. Typically there is a group of trees of the same or different kind: pines, firs, birches, etc. Often one of them is older than others. Between the trees, there are one or several miniature wooden chapels with figurines of St Mary, Jesus Christ, or Saints as well as just crosses. The latter used to be monumental (those erected on the ground) or small pieces nailed to the tree trunk. Such an ensemble is traditionally surrounded by a stone wall or a simple fence (Fig. 2). Sometimes the ensemble also incorporates a natural or artificial well inside or, more often, outside the boundaries. Collective religious

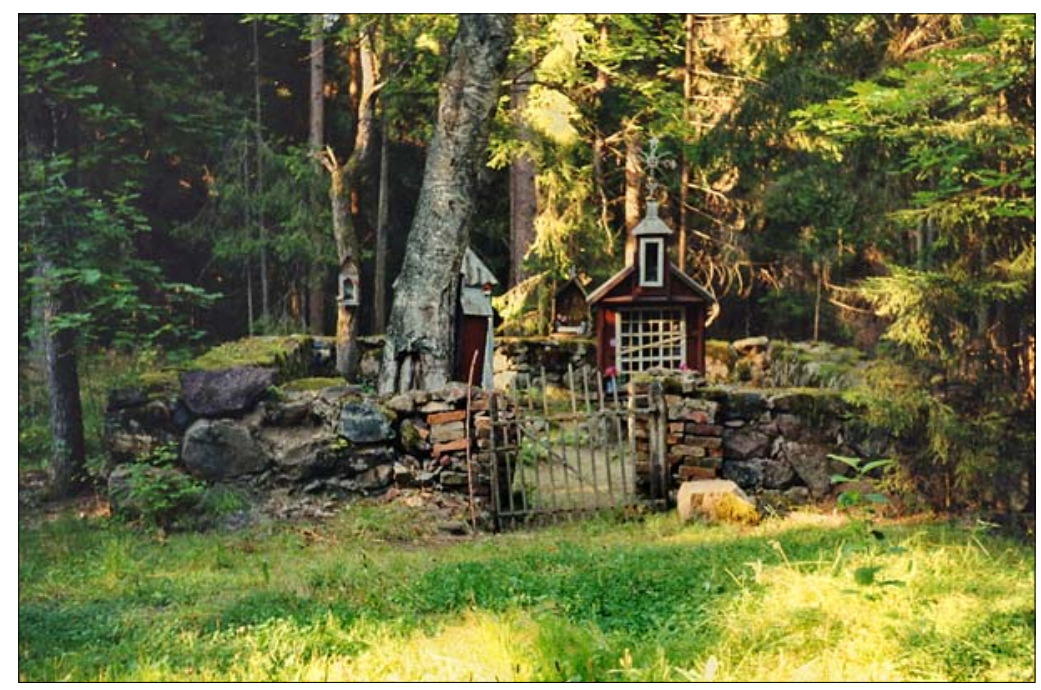

Figure 2. The natural holy place located in the forest near Kiršai (Telšiai District). Photo by Saulius Lovčikas (1995). Courtesy of the author. 


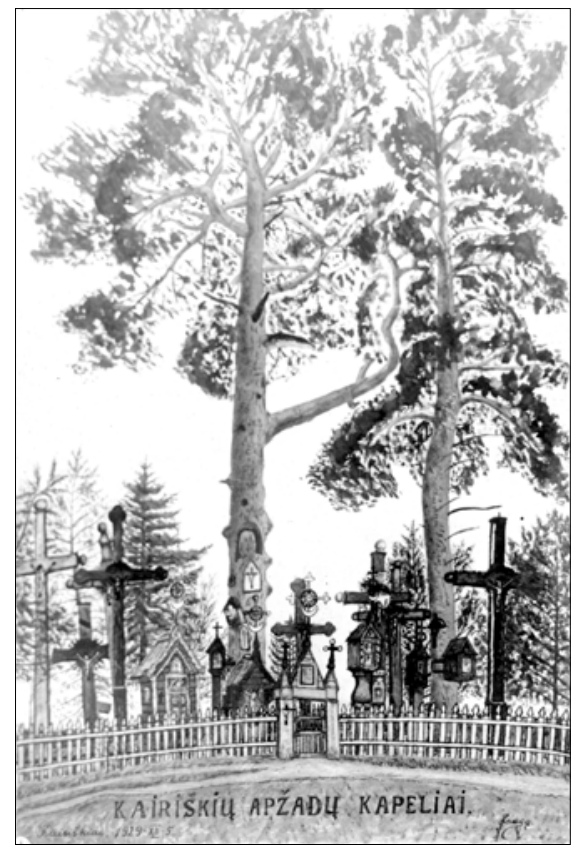

Figure 3. Apžadų kapeliai ('Vow's cemetery') located near Kairiškiai (Akmen District). Drawn by Jauga (1929). Courtesy of B. Kerys.

activities were practised here once a year, usually in summertime. In the recent past, an ancient method of banging a wooden board hung on a tree in the holy place was used to call people together for a common prayer.

While talking about the relationship between trees and Christian objects in the holy place, it should be pointed out that the religious focus is usually on figurines placed inside the chapel. The surrounding trees serve as supporters of crosses, chaplets and other small objects, as the custom of taking vows and offering votives is extremely dominant in this region. Yet, legends about the origin of such local holy places incorporate trees into particular mythological events. For example, it is told that the figurine of Jesus Christ was found in the tree and a candle was burning beneath and that it was a sign for people to build a 'house of god' (= chapel) in this holy place.

In general terms, this type of sacred groves embodies both pagan and Christian religious ideas. A grove with a group of trees in its centre is still an acceptable environment for Christian and sometimes semi-Christian ritual practices.

For further research, it is worth mentioning that some of the above described groves (groups of trees) function at the same time as cemeteries (Fig. 3). It seems that burials took place there irregularly (e.g., during wars) but it is impossible to determine which function emerged first. Now both religious aspects are, say, interdependent cults. For example, Hail Mary prayers may take place in the period typical of the commemoration of the dead (in autumn), or one may set up a cross in commemoration of missing men in such a holy place.

Separate trees like oaks, limes, firs, and especially pines are regarded as sacred, too. Sometimes the sacredness of a tree clearly depends on its location as demonstrated by examples of trees growing near churches or on the territory of rural cemeteries. Nobody was allowed to cut down such trees, except for Catholic priests fighting against elements of paganism in their parish (Fig. 4).

Furthermore, sacred trees are often located simply at the roadside or the crossroads (Fig. 5). Sometimes they are just objects that people pass by on their way to natural holy place and/or cemetery. This aspect very likely affects 


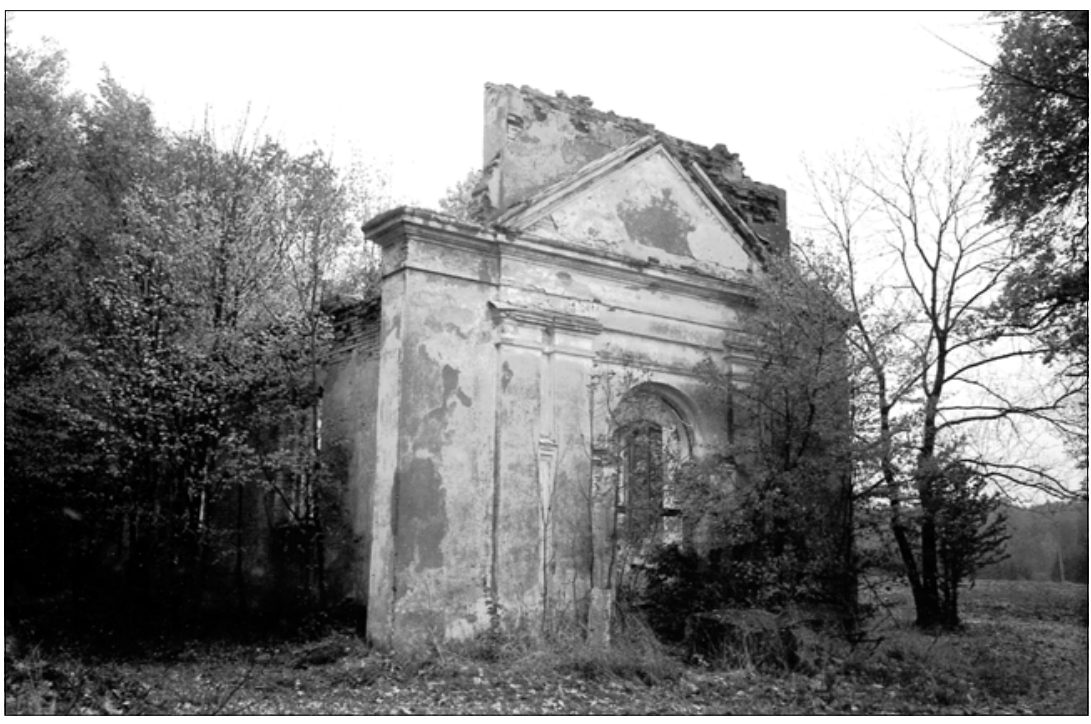

Figure 4. The so-called Fridays' site near Digriai (Kaunas District). Built in 1837 near the sacred ash chapel of Jesus' Heart, it was widely known as a place where Mass was held every Friday, as well as a pilgrimage destination. There was a double-stem ash grown into one at the back of the building until the priest ordered it to be cut down (soon after the chapel was consecrated). Photo by Vykintas Vaitkevičius (1990).

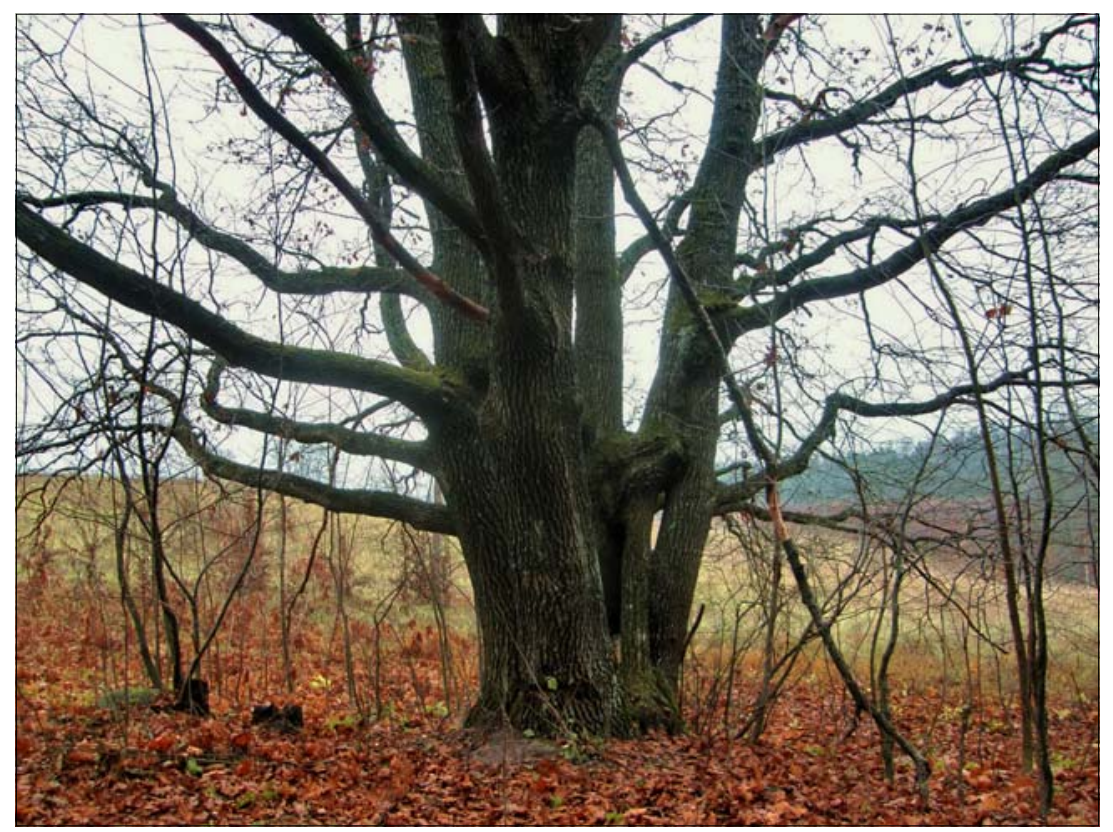

Figure 5. The sacred oak near Užukalnis (Prienai District), which is famous for its six holes shaped by multiple trunks and branches grown together. A special healing ritual which involved going naked through one of the holes at sunrise was carried out at the tree. Photo by Vykintas Vaitkevičius (2008). 
human behaviour and inspires people to perform certain ritual activities: offering a small votive (e.g., coins), carving a cross-sign on the tree trunk, erecting a small cross of two bound branches, or just praying there. Thus, in this context, sacred trees definitely appear as sacral objects and significant landmarks.

Sacred or (based on somebody's hunch) inviolable trees like oaks, limes, ashes, maples, and others, are often located also on the territory of farmsteads. These trees are usually associated with ancestors who have lived on the farm and have planted a particular tree. The custom of planting a tree on the occasion of childbirth in the family was widely practised. The tradition spread sporadically even as late as in the middle of the 20 th century. The trees growing near or in the yards of residential houses in rural areas are much older. Because of their old age and the preserved memory of ancestors, they were sometimes decorated with small wooden chapels or crosses. No significant ritual activities surrounding the sacred trees of this type are known but everyone who intended to cut down the tree in the farmstead must have paid respect to former generations (by paying for the Mass or giving alms to the beggars) (Vèlius 1975: 238ff).

In sum, there are many doubts as to whether it is possible to reconstruct ancient mythology and rites connected with groves that have disappeared in the landscape at some point in the past. But the tradition of sacred groves, smaller groups of trees, and separate trees, which, according to historical sources, can be traced back to pre-Christian times, is still enduring in the modern society. It seems reasonable to assume that the key idea of the grove has not significantly changed over the centuries. The part of the natural world that was unfamiliar to people was perceived as if another world on earth, as it was believed to hold supernatural powers represented by gods and the dead. And finally, even today a grove is chosen as a place for praying.

\section{LOST HISTORY AND MODERN RESEARCH}

Modern research into the natural holy places often entails also sacred groves. A number of these were registered during the regional registration of sacred groves (see Vaitkevičius 1998, 2006). Place names, particularly 'Gojus grove’, are most commonly used as evidence of the existence of sacred groves. Next to the place names, in-depth investigations have enabled scholars to discover major complexes of data consisting of linguistic, historical as well as folkloric evidences. The obtained information has been analysed relative to the actual landscape. 
A selection of sacred groves which have been discovered in recent years can be presented:

(1) Gojus grove located nearby Kernavè (Širvintos District, East Lithuania) should be considered an element of a famous archaeological complex of five hillforts, some burial grounds and barrow groups, unfortified settlements, etc. As the last stage of this complex is dated back to the 13th to late 14th century, the sacred grove very likely belongs to the same period. In the second half of the 13 th century, Kernave was the residence of Traidenis, the Grand Duke of Lithuania (1269-1282). His estate was located on top of the hillfort called Aukuro kalnas. Nearby the Gojus grove there is a site called Kriveikiškis (krivis 'chief (pagan) priest', krive' 'assemblage').

Oral tradition is of considerable importance in this location. It was purposefully recorded only at the beginning of the 21st century and has revealed some unique aspects of the phenomenon of sacred grove (see Piasecka et al. 2005: 246ff). For example, in several accounts the conversion of the people of Kernave to Christianity has been described. According to legends it took place precisely in the above-mentioned grove beneath a sacred oak. One particular phrase based on this legend and Lithuanian history in general was known even in the 20th century - namely, Polish Catholics recurrently told Lithuanian Catholics that the latter should go to the oak in the Gojus grove and renew their knowledge of Christianity (prayers, making cross-signs, etc.). Whether it is true or not, but one particular stump is still believed to be that of the onetime sacred oak.

(2) Another Gojus grove worth mentioning is located near the city of Elektrènai, Central Lithuania (founded on the grounds of the former Perkūnakiemis village - its name was derived from the words Perkūnas 'god of thunder' and kiemas 'village'). There was a stump of a sacred oak known some time ago as well.

Historically, Perkūnakiemis was a settlement of noblemen and was established in the 17th century, while the barrow group located in the Gojus grove in East Lithuania indicates that the sacredness of the natural holy place may have its roots in the pre-Christian period, as late as the 11th-12th century (judging by a random find of a burnt wide-bladed axe).

Perkūnas (the god of thunder) is the most striking character in the local narrative tradition even today. According to old legends he miraculously downed a Swedish army in this locality. He later also administered justice. Remarkably, one particular legend connects the genealogy of the Laimutis family with a sanctuary in the Gojus grove. The surname Laimutis stands for someone who is lucky in the direct sense of the word, while laime represents the concept of fortune itself and Laima is the goddess of fortune. Diminutive suffix -utis 
expresses kinship relations between father (Laimis) and son (Laimutis). The family name Laimutis is spread in a relatively narrow area (Vanagas 1989: 1617) and was never replaced by the Slavic equivalent Sčesna or Česna.

(3) The former site of the sacred grove called Šventos Liepos ('Sacred Lindens', originally recorded in Polish as Swiato Liepe, Les Swiatolipie) is located near the city of Trakai (Naujieji Trakai) - the favourite residence of the Grand Duke of Lithuania in the late 14th-early 16th century. The grove still existed in the 16th-18th century but had belonged to the nobles of Tottori origin since the late 15 th century.

A recent detailed investigation revealed that the Sacred Lindens grove located on a peninsula in Lake Galve constituted an element of a complex natural holy place covering the entire northern part of the lake including its islands, basin and the hilly lakeshore. According to folk etymology, the name Galve is connected with the word galva 'head' and for that reason it is believed that the lake requests human sacrifice twice a year: just before freezing and at the time the ice melts. Surprisingly, in 1923 a fisherman accidentally found two unique artefacts there: human heads (measuring $7 \times 11 \mathrm{~cm}$ and $6.5 \times 8.9$ $\mathrm{cm}$ ), carved in sandstone, which today are held in the Trakai History Museum.

(4) The former site of the sacred grove called Kukaveitis (the name has been derived from Kukas denoting one of the mythological beings and veita 'place') is located near Maišiagala (Vilnius District). According to Historia Polonica written by Jan Dlugosz in the 15th century, the Grand Duke Algirdas was ceremonially burned in 1377 in the Kukaveitis (originally Latin Kokiveithus) ${ }^{3}$ grove (Vèlius 1996: 556).

No traces of it having been a cultic place have been identified so far, but the natural boundaries (slopes of the hill) and the geographical description of the area date back to the 18th century. At the time, the former territory of the Kukaveitis grove was occupied by some scattered farmsteads, already called by the same name, Kukaveitis. Recently, two East-Lithuanian barrow groups were discovered to the north and east of the Kukaveitis grove site, and some destroyed cremation burials dated to the 10th-11th century were discovered. A bronze ring-shaped brooch from the late 14th century was accidentally found there as well.

All the discussed examples, in particular those described under points (1), (3), and (4), are highly compatible with the historical evidence of the 16th century concerning the Lukiškes sacred grove in Vilnius, the capital of the Grand Duchy of Lithuania during its pagan period. The presence of sacred groves in the very surroundings of Kernave (the first known residence of the Grand Duke), Trakai (the second), and Vilnius (the third), indicate the importance of groves in the pre-Christian religion of the period of the Grand Duchy of Lithuania (c. 1183/1236-1387). However, there is still no precise answer as to whether 
these groves were connected with the religion in a passive way (perhaps just in mythological perceptions) or were used as a space for active ritual practices (e.g., hunting and sacrificing on special occasions, cremation or burying of the dead).

Later periods in the history of sacred groves are much more accurately represented, although it is generally acknowledged as the time of decline. Besides, Christianity became a factor that has significantly influenced the former nature of the tradition. The large amount of data concerning the sacred groves that has been discussed in this article illustrates the remarkable linguistic background (the alka concept), the historical context (natural holy places usually accommodate some other sacral objects) and numerous references to sacred groves in folklore. Archaeological evidences are rather scarce but the subject could be expanded in the course of research into particular features of cultural landscape in the near future.

Finally, it should be underlined that a non-complex approach to the sacred groves (which is still practiced by linguists, historians and folklorists) cannot benefit the research. Methods used by natural sciences would offer different stimulating possibilities for investigating sacred groves and former grove sites, even though it has never been tested in Lithuania so far.

\section{NOTES}

1 The number of copies of this publication, which was published at the Baltic University in Tübingen, Germany just after the Second World War, was unfortunately extremely limited.

2 It is even believed that this concept, which is rooted in the worldview of the Baltic tribes, should be regarded as the very first historical stage of the development of the protected areas in modern Lithuania (Baškytè et al. 2006: 7-8).

3 Other variations of this place name in the 16th- to 18th-century documents are: KaKoweytis, Kukaweytis, Kukowajtys, etc.

\section{REFERENCES}

Balčikonis, Juozas (ed.) 1941. Lietuvių kalbos žodynas. [Dictionary of the Lithuanian Language.] Vol. 1. Kaunas: Institute of the Lithuanian Language.

Balys, Jonas 1966. Lietuvių liaudies pasaulejauta tikejimųir papročių šviesoje. [World Conception in Lithuanian Folklore.] Chicago: Draugas.

Baškyte, Rūta; Bezaras, Vidmantas; Kavaliauskas, Paulius; Klimavičius, Algimantas \& Raščius, Gediminas (eds.) 2006. Lietuvos saugomos teritorijos. [Protected Areas in Lithuania.] Kaunas: Lututè. 
Dundulienè, Pranè 1979. Medžiai senoves lietuviцtikejimuose. [Trees in the Beliefs of Ancient Lithuanians.] Vilnius: Mintis.

Ivinskis, Zenonas 1938/1986. Medžių kultas lietuvių religijoje. [Cultus arborum in antiqua religione lituanorum.] In: P. Jatulis (ed.) Rinktiniai raštai. Roma: Lietuvių Katalikų Mokslo Akademija, Vol. 2, pp. 348-407. [Offprint from Soter, Vol. 15, pp. 140-176 and Soter, Vol. 16, pp. 113-144.]

Karulis, Konstantīns 1992. Latviešu etimoloğijas vārdnīca. [Latvian Etymologial Dictionary.] Vol. 1/2. Rīga: Avots.

Lukšaite, Ingè (ed.) 2006. Matthaeus Praetorius. Deliciae Prussicae, oder Preussische Schaubühne. Vol. 3. Vilnius: LII leidykla.

Martinkus, Ada 1989. Eglé, la reine des serpens. Paris: Institut d'éthnologie.

Piasecka, Beata; Stankevičiūtè, Ida \& Vaitkevičius, Vykintas 2005. Vilniaus apylinkių padavimai. [The Local Legends of the Vilnius Region.] Tautosakos darbai. Vol. 22 (29), pp. 219-261.

Šturms, Eduards 1946. Die Alkstätten in Litauen. Contributions of Baltic University. Vol. 3, pp. 1-35.

Šturms, Eduards 1948. Baltu tautu svētmeži. [The Baltic Holy Groves.] Sauksme. Vol. $1 / 2$, pp. $17-21$.

Urtāns, Juris 1989. Sviashchennye lesa i roshchi v Latvii. [Holy Forests and Groves in Latvia.] In:Arkheologiia i istoriia Pskova i Pskovskoi zemli 1988. Tezisy dokladov nauchno-prakticheskoi konferentsii. Pskov, pp. 61-63.

Vaitkevičienè, Daiva 2001. Ugnies metaforos. Lietuviųir latvi umitologijos studija. [Metaphors of Fire: A Study of Lithuanian and Latvian Mythology.] Vilnius: Lietuviu literatūros ir tautosakos institutas.

Vaitkevičius, Vykintas 1998. Senosios Lietuvos šventvietes. Žemaitija. [The Sacred Sites of Lithuania. Samogitia.] Vilnius: Diemedžio leidykla.

Vaitkevičius, Vykintas 2004. Studies into the Balts' Sacred Places. BAR International Series, 1228. Oxford: John and Erica Hedges, Ltd.

Vaitkevičius, Vykintas 2006. Senosios Lietuvos šventvietes. Aukštaitija. [Ancient Sacred Places of Lithuania. Aukštaitija (Upland) Region.] Vilnius: Diemedžio leidykla.

Vanagas, Aleksandras (ed.) 1989. Lietuvių pavardžių žodynas. [Dictionary of Lithuanian Family Names.] Vol. 2. Vilnius: Mokslas.

Vèlius, Norbertas (ed.) 1975. Šiaurés Lietuvos sakmes ir anekdotai. Surinko M. Slančiauskas. [North-Lithuanian Narratives and Jokes. Collected by M. Slančiauskas.] Vilnius: Vaga.

Vèlius, Norbertas (ed.) 1996. Baltų religijos ir mitologijos šaltiniai. [Sources of Baltic Religion and Mythology.] Vol. 1. Vilnius: Mokslo ir enciklopedijų leidykla.

Vèlius, Norbertas (ed.) 2001. Baltų religijos ir mitologijos šaltiniai [Sources of Baltic Religion and Mythology.] Vol. 2. Vilnius: Mokslo ir enciklopedijų leidykla.

Wenskus, Reinhard 1968. Beobachtungen eines Historikers zum Verhältnis von Burgwall, Heiligtum und Siedlung im Gebiet der Preussen. In: M. Claus, W. Haarnagel \& K. Raddatz (eds.) Studien zur europäischen Vor- und Frühgeschichte. Neumünster: Wachholtz, pp. 311-328. 